\title{
Rethinking habits and their role in behaviour change: The case of low-carbon mobility
}

\author{
Tim Schwanen ${ }^{a, *}$ \\ David Banister ${ }^{a}$ \\ Jillian Anable ${ }^{\mathrm{b}}$ \\ a Transport Studies Unit \\ School of Geography and the Environment \\ University of Oxford \\ b The Centre for Transport Research \\ School of Geosciences \\ University of Aberdeen \\ * Corresponding author \\ South Parks Road \\ Oxford, OX1 3QY \\ England \\ Tel: $+44-1865-285503$ \\ Fax: +44-1865-275885 \\ E-mail: tim.schwanen@ouce.ox.ac.uk
}

Prepared for the special issue:

Theoretical Perspectives on Climate Change Mitigation in Transport Journal of Transport Geography

First submission: 22 August 2011

Revised submission: 16 April 2012 


\title{
Rethinking habits and their role in behaviour change: The case of low-carbon mobility
}

\begin{abstract}
With the emergence of behaviour change on political and intellectual agendas in passenger transport, the question of how to understand and intervene in habitual carbon-intensive travel practices has become crucially important. Building primarily on the philosophies of Félix Ravaisson and John Dewey, we outline an approach to travel habits that is more affirmative than prevailing psychological perspectives. Rather than as the automatically cued, repetitive behaviour of individuals, habit is understood here as a generative and propulsive capacity brought about through repetition and belonging to body-mind-world assemblages that exceed the human individual as conventionally understood. The implications of the proposed conceptualisation of habits for behaviour change are also explored. We argue that widespread, durable behaviour change is unlikely to result from the displacement of automaticity by reasoned action alone but instead demands changes in collective customs. Additionally, a narrow focus on breaking carbon-intensive travel habits should be avoided. Not only should the formation of low-carbon habits and associated forms of embodied intelligence be stimulated; it is also important to capitalise on the potential for subtle change immanent to carbon-intensive travel habits in situations where individualised vehicular travel is the only realistic transport option.
\end{abstract}

Keywords: behaviour change; habit; travel practices; low-carbon mobility; Ravaisson; Dewey 
"We are, it is clear, a long way now from any thought of rational economic man, or indeed many other variants on this model of being human; it is commonplace nowadays that persons are not discrete islands of consciousness and agency."

Thrift (2008a, page 87)

\section{1| Introduction}

Certainly within the UK context 'behaviour change' has recently become something of a mantra that has appeared on political and intellectual agendas with considerable force. In domains as diverse as public health, anti-social behaviour and public order, energy use and passenger transport, UK policy now holds that citizens must take their responsibility and modify behaviours voluntarily for substantial change to materialise (e.g. Halpern et al., 2004; DEFRA, 2008; Dolan et al., 2010; DfT, 2011). This emphasis on behaviour change has a complex genealogy and transcends classic distinctions in the political arena (Jones et al., 2011; Pykett, 2012). It is entangled with the popularisation of 'libertarian paternalism', which is a form of governing that moulds the contexts of an individual's decision-making whilst also increasing the range of available choices for shaping his/her own life; the idea is to both increase choice and ensure welfare (ibid.; Thaler and Sunstein, 2008). The growing significance of behaviour change and libertarian paternalism needs to be positioned against two wider developments. One is the more general shifting and re-scaling of responsibilities away from the national state towards the individual as an active agent in the creation of the self and indeed society, that is characteristic of Anglo-American advanced liberal democracies (Rose, 1996). The other is the proliferation of research in behavioural economics, psychology, marketing studies and the neuro-sciences - work that is united in its qualification of Homo Economicus, work also that has come to exert a profound influence on policy discourses with regard to climate change mitigation in the UK and the USA.

Paralleling tendencies in governance and policy-making, transport academics now agree that at least some level of behaviour change is unavoidable if carbon emissions from transport are 
to be reduced significantly (Banister, 2008; Boarnet, 2010; Anable et al., 2012). Debate continues, however, as to how much behaviour change is required and which mechanisms are most effective in decarbonising passenger transport. While classic economic instruments (pricing, taxing) and urban compaction and transit-oriented development continue to be favoured widely (Ewing et al., 2008; Boarnet, 2010), 'soft' policy measures and smarter choices have attracted increased attention in recent years (Cairns et al., 2008; Bamberg et al., 2011). Though there is no one-to-one relation, thinking about soft policy measures in transport resonates with wider developments in policy discourses and Western societies. Both are largely individualistic and premised on the idea that the individual - as the key agent who chooses, interprets and ascribes meanings to travel patterns - is an essential site for bringing about change through public policy. Also, habits are central to both. Habit is here understood typically as more or less automatic behaviour acquired through repetition and positive reinforcement, and the challenge is to break or defrost unsustainable, carbon-intensive habits (cf. Gärling and Axhausen, 2003; Matthies et al., 2006; Verplanken and Wood, 2006).

The current paper has a threefold aim. It firstly provides a sympathetic critique of the prevailing, mainly psychology-based conceptual frameworks underpinning thinking about behaviour change towards low-carbon mobility in the academic literature, focusing particularly on common understandings of habit. We submit that mainstream understandings are problematic in various ways and argue that transport researchers interested in behaviour change should also embrace ways of thinking about human action that are not directly grounded in recent developments in the disciplines of psychology and economics. Such theoretical diversification is beneficial: it opens up further ways of intervening in travel patterns and allows some unhelpful conceptualisations regarding low-carbon transport - in particular the juxtaposition of technology versus behaviour change and the distinction between hard and soft policy measures - in academia and beyond to be circumvented. Secondly, we begin to outline an alternative way of thinking about habits and behaviour change with strong Aristotelian roots that builds on the philosophies of Félix Ravaisson and John Dewey. Finally, we discuss the implications of our perspective on habits for the decarbonisation of passenger transport. However, before introducing the thoughts of 
Ravaisson and Dewey, we begin with a review of the academic literature about behaviour change in passenger transport.

\section{2| Behaviour change, habit and transport-related research}

The first thing to note about that literature is its diversified character. Multiple theoretical frameworks - primarily from economics and psychology - are used to frame empirical research. Not all research is strongly theoretical however: part of the literature has a strong pragmatic character and tries to establish to what extent interventions to change travel patterns produce the desired effects. This holds true, for instance, of much work on personalised travel planning (PTP), whereby people are provided with carefully targeted information and assistance with the objective of bringing about voluntary behaviour change away from car driving (Bonsall, 2009; Brög et al., 2009). Whilst PTP's origins lie in social marketing (Bonsall, 2009), concerns over the effectiveness of interventions prevail over theory development in the associated literature.

Nonetheless, much of the research on behaviour change in passenger transport is informed to varying degrees by attitude theories from social psychology, such as the Theory of Planned Behaviour (TPB) (Ajzen, 1991), the Theory of Interpersonal Behaviour (Triandis, 1977) and Schwartz's (1977) Norm-Activation Model. These frameworks have become increasingly popular in transport-related research over the past decade (e.g. Matthies et al., 2002; Bamberg and Schmidt, 2003; Polk, 2003; Anable, 2005; Gardner, 2009; Klöckner and Blöbaum, 2010; Bamberg et al., 2011). It is beyond the scope of this paper to discuss the intricacies of the rich and diversified literature in which attitude theories are used to better understand behaviour change in transport; however, there are two trends that are particularly relevant in the context of the current paper. Firstly, the voluntarism characteristic of many attitude theories has been mollified and the significance of constraints on choice and behaviour is increasingly appreciated (Gatersleben and Vlek, 1998; Haustein and Hunecke, 2007; Hunecke et al., 2007; Klöckner and Blöbaum, 2010). Thus, in many attitude theory- 
based empirical studies travel behaviour is considered the outcome of both choice and constraints.

Secondly, the importance of habit in transport mode usage has been recognised increasingly. The research by psychologist Bas Verplanken and colleagues has been profoundly influential here: in a number of studies focusing on car use they have criticised the TPB for failing to consider how habits mediate the link between behavioural intention and actual behaviour (Verplanken et al., 1994, 1997; Aarts and Dijksterhuis, 2000). Habit is here understood as an automatically elicited behaviour, whereby the presence of particular cues in the performance context - examples include the specific location where a person is, the preceding actions in a sequence, and the presence of particular people - automatically triggers the behaviour in question (Orbell and Verplanken, 2010). This automatic elicitation, the argument goes, comes about because it is cognitively efficient. Over time, an attitude-based and thus deliberationbased behaviour may become habitual if it repeatedly proves to be adequate and satisfactory. The cognitive effort that goes into deliberative decision-making is short-circuited with continual positive reinforcement, and the behaviour in question becomes - after Schank and Abelson (1977) - script-based (Gärling et al., 2001; Gärling and Axhausen, 2003; Gardner, 2009). From this evolves the hypothesis that a strong relationship between past behaviour and later behaviour proves that the behaviour in question is habitual (Oullette and Wood, 1998). Indeed, frequency of past behaviour has been used as a measure of habit strength in many studies and is typically found to significantly improve the prediction of later behaviour over and above the effects of attitudes and intention (ibid.).

Building on this line of reasoning, psychologists and others have emphasised the importance of breaking or defrosting habits to behaviour change (Matthies et al., 2006; Verplanken and Wood, 2006): automaticity needs to be displaced by reasoned action. This can be done by disrupting either a person's automatic response or the performance context cuing that response (Darnton et $\mathrm{al}_{,}, 2011$ ). The former strategy is exemplified by the generation of implementation intentions - if-then plans that individuals adopt and rehearse so that new habits can come into being (Gollwitzer, 1999) - in individuals. Transport-related experiments 
suggest that implementation intentions can weaken existing and facilitate the emergence of new travel habits (Bamberg, 2002; Eriksson et al., 2008) but a recent review by Darnton et al. (2011) suggests that such intentions may be less effective if habits are entrenched more deeply. Habit-breaking strategies revolving around cues seem to have attracted slightly more widespread attention in the transport literature. A range of studies have examined to what extent car use habits can be broken through interventions modifying the costs and benefits associated with habitual and alternative behaviours. Examples are temporary price promotions, such as the provision of free bus travel for a specified time period (Fujii and Kitamura, 2003; Matthies et al., 2006; Thøgerson, 2009), and temporary changes to infrastructural conditions, such as road closures (Fujii et al., 2001). Some of the experiments conducted have been rather successful in terms of bringing about modal shift although the long-term effects warrant further research. It has also been emphasised that the timing of habit-breaking interventions matters: these may be more effective when a life event occurs, as is the case when people move house, take up a new job, or when a child is born (Verplanken et al., 2008).

A key advantage of attitude theory-inspired studies of travel behaviour change and habits is that they generate insights that can fairly easily be translated into tailored policy interventions. There are, however, various limitations over and beyond the observation that most academic studies have been largely restricted to transport mode use and not paid due attention to other dimensions of travel behaviour that are relevant to transport's decarbonisation, such as travel distance and destination choice. One concern is that most attitude theory-inspired studies assume attitudes and beliefs to precede and causally determine behaviour and habit formation; more complex patterns of causality, such as bidirectional or reversed causal relations, tend not be taken into account. This is in spite of the existence since the mid-1970s of a number of travel behaviour studies that have shown alternative patterns of causality to fit empirical data about travel behaviour and attitudes better than the causal structures embedded in attitude theories (Dobson et al., 1978; Golob et al., 1979; Golob, 2001; Bagley and Mokhtarian, 2002). 
Another issue is that value-action gaps pertaining to differences between persons' stated values and intentions and actual behaviour continue to constitute a major challenge for attitude theories (Shove, 2010). The incorporation of habit as a driver of behaviour - thus reducing or eliminating the extent to which action is preceded by deliberation and the formation of attitudes and intentions - to some extent mitigates value-action gaps. However, including the frequency of past behaviour to measure the habit construct in models for explaining intended or actual behaviour is to some extent tautological and cannot be confirmed empirically: both dependent and independent variable may well be measuring one and the same thing - a general tendency to perform the behaviour in question.

A further concern is that psychology-oriented studies of behaviour change in passenger transport tend to understand habit primarily in terms of automaticity and mechanical repetition, as a phenomenon originating in the workings of the mind, and as inhibiting reflective thought. As we will argue below, this is a one-sided and overly restricted conceptualisation of habit, one that does not do justice to the complexity and richness of habits in everyday life. Finally, implicit in much of the work on habit deconstruction is a privileging of reflective, evaluative thought originating within the subject as the proper basis for action over other forms of interacting - semi-conscious, reflexive, instinctive - with the environment in which a person is situated. ${ }^{1}$ This privileging of reflective thought also entails the implicit assumption that all such thought consists in an instrumental, logically structured weighing up of alternatives. Sidelined is the fact that reflective thought and decision-making comes in many different modalities and can also be chaotic and lock people into circuits of indecision (Bissell, 2011; McCormack and Schwanen, 2011). These last two points in particular bear witness to the Cartesian and Enlightenment roots of attitude theories. Not only are they based on the assumption of a sovereign, autonomous subject for whom

\footnotetext{
${ }^{1}$ It should be appreciated that behavioural economics takes a different perspective in this regard. This approach customarily distinguishes two systems of thought - one is reflective, the other automatic - and habit is thought to be crucial to the latter. It suggests that one way to bring about behaviour change is to work with the tendencies in the automatic system of thought. Thus, behaviour change does not necessarily demand the deconstruction of habits and the opening up of a space for reflective thought; it can also ensue from "going with the grain of behaviour: harnessing the ... automatic effects to nudge people onto a different, selfsustaining, track" (Dolan et al., 2010, page 77; see also Thaler and Sunstein, 2008).
} 
reflective thought is the basis of human existence (cogito ergo sum); they also take the Cartesian body-mind dualism for granted and privilege mental processes over embodiment. Philosophers, social theorists and neuro-scientists (e.g. Merleau-Ponty, 1962[1945]; Damasio, 1994; Thrift, 2007) have all challenged these assumptions, and views of the type espoused in the opening quote of this paper are commonplace in social and cultural theory.

Against this background, in this paper we explore what becomes possible in terms of imagining behaviour change in passenger transport once the assumption of a sovereign subject is suspended, embodiment foregrounded, and habit re-imagined. Our approach operates somewhere in the vicinity of 'practice theory' in sociology and human geography (Reckwitz, 2002; Darnton et al., 2011; Watson, this issue). Yet we part company with practice theory's conflation of habit with the outward performance of routine movement and action. Bundles of actions or practices like routinely commuting by car or working on the train are representations of habit (Bissell, 2012); habits are the tendencies or forces implicated in such routine performances. Our approach is best understood as part of the mobility turn in (cultural) sociology and geography (Sheller and Urry, 2006); aligned with recent work on habits in geography (Thrift, 2008b; Dewsbury, 2011; Middleton, 2011; Bissell, 2011, 2012); and animated by the movements of pragmatism, post-structuralism and phenomenology in philosophy and thinking about socio-technical transitions in innovation studies (Geels, this issue).

\section{3| The centrality of habits}

The approach to thinking about behaviour change we advocate rests on two key premises. The first is that habits are even more central to everyday behaviour than many psychologists of habit suggest. Following John Dewey (1922), Maurice Merleau-Ponty (1962[1945]) and others, we consider habits to be primordial to deliberative action. As embodied beings, humans participate in and make sense of the world in ways that are predominantly practical, unreflective and habitual; reflection and intelligibility come from sensuous experience and 
practice rather than the reverse (see also Bissell, 2011). The second premise is that the notion of habit itself needs to be reconsidered. Rather than as automatic response to certain cues, habit needs to be thought of as a tendency or force.

With regard to the second point, it is useful to identify two traditions in thinking about habit in Western thought. The first is the tradition in the wake of Descartes and Kant, for whom habit equalled pure mechanism, a routine process, a threat to the freshness of reflective thought (Malabou, 2008; Carlisle, 2010). In this line of reasoning habit is understood variably as more or less automatic behaviour or as the capacity to act unreflectively in a particular way, both of which are learned or acquired through repetition and reinforcement (Carlisle and Sinclair, 2008a; Orbell and Verplanken, 2010). Within this perspective the positive role of habits in everyday life, such as their functionality in reducing the cognitive complexity of everyday actions, is acknowledged. Yet there is a tendency to concentrate on habits as barriers to and inhibitors of reflective decision-making and behaviour change. Obviously, then, this is the perspective on habit that prevails in the transport-related literature discussed above.

The other tradition goes back to Aristotle, for whom "moral virtue comes about as a result of habit" (1980[n.d.], Book II, 1103a), and comprises at least two lineages. One comprises a series of philosophers in $19^{\text {th }}$ and $20^{\text {th }}$ century France, including Maine de Biran, Bergson, Merleau-Ponty, Ricoeur, Deleuze and Ravaisson; the other consists of a number of American thinkers around the turn of the $20^{\text {th }}$ century and includes Thorstein Veblen, William James and John Dewey. There are significant differences between and within these lineages; however, a unifying idea across this tradition is the proposition that habit is more than the "mechanisation of activity ... that is always bound to reproduce itself in the same way" (Burkitt, 2002, page 227) and rather a capacity or a disposition and fundamental way of being. Habit, then, is about stability and change. It is about one of the key issues in (continental) philosophy - being and becoming.

\section{1| Ravaisson on habit}


One of the most original and comprehensive contributions to thinking about habits is Of Habit (2008[1838]) by Félix Ravaisson. He considered acquired habit a general and stable way of being, an active tendency that develops through the continuity of change, not only in humans but in all forms of organic life. ${ }^{2}$ Central to his approach is what he called the 'general law of habit'. On the one hand, a being's ability to undergo change - termed receptivity by Ravaisson - decreases with each repetition, so that changes coming from outside that being alter it less and less with each occurrence. On the other, a being's ability to initiate change called spontaneity - increases with each repetition, so that the changes it initiates tend to reproduce themselves with increasing ease and with less effort. The combined result of declining receptivity and increasing spontaneity is that a given capacity becomes a being's second nature.

On one level it could be said that Ravaisson distinguishes between 'passive' and 'active' habits. The former pertain to the situation in which one or more entities have an impact on a human being or organism. Ravaisson uses the term sensibility to denote this situation. The latter refer to the situation whereby a being has an impact on other entities and itself and which he labels movement. However, the active/passive distinction is too simple as there are always active elements in sensibility (e.g. perception) and passive elements in movement (e.g. the impression of effort on its instigator). Nonetheless, we can take Ravaisson to imply that habituation entails a redistribution of activity and passivity. Consider as an example of sensibility someone who tries to sleep in a very noisy environment. The balance between passivity and activity shifts with the lapse of time: gradually she becomes used to the noise, so that the difference "between the state of the sensed object [i.e. the sounds sensed] and the state of the sense" (Ravaisson, 2008[1838], page 51) is reduced; her body adapts, some form of equilibrium emerges and she is dulled to sleep. An "obscure activity" (ibid.), or need for the sounds, has come into being that increasingly anticipates the impression from outside. When the noise stops, this internal activity and disposition towards the sounds is disrupted:

\footnotetext{
${ }^{2}$ For Ravaisson habit was a medium to explore the constitution of nature and for arguing that organic life cannot be understood solely in terms of mechanism and determinism.
} 
she 'misses' them and may well wake up. Now, if we substitute urban congestion during peak hour for noisy environment, we can suspect many drivers encountering this circumstance at first to be impatient and frustrated: they are forced to wait and slow down given that what Bergson (1911[1907]) called their duration - the lived experience of time passing - is hooked together with the durations of other road users and the infrastructure used. Over time and with repeated occurrence, however, they start to adapt and unreflectively come to use the time in slow traffic for a host of purposes, such as relaxing, thinking or calling relatives. They may develop a 'need' for this downtime and some may even miss it once congestion is reduced after policy interventions and in the longer term become less resistant to a longer home-to-work distance (see also Salomon and Mokhtarian, 1998).

Along similar lines, activity recedes with repeated movement (here understood in Ravaisson's sense as a being impacting other entities). This is, for instance, what happens with cycling: with repetition effort and resistance become less, and the action is perfected and becomes increasingly involuntary. It turns into a tendency that anticipates rather than follows from reflective thought and consciousness, and after some time escapes reflection altogether. This tendency can be considered an expression of desire, which develops and intensifies with repetition and continuation (Carlisle and Sinclair, 2008b). What can be seen here is how, for Ravaisson, habit helps us to overcome dualisms and functions as a middle term between opposites - here reflective thought and instinctive action, and mind and body. With habituation movements involving and requiring reflective thought become increasingly involuntary and embodied such that a person's organs involved become imbued with a certain form of intelligence. The actions triggered by this embodied intelligence are almost, but not entirely ${ }^{3}$, instinctive. As we will see below (section 4.2), this embodied intelligence explains not only why people do something like cycling without much effort but also why they undertake the act in the first place.

The above implies that habit and reflective thought are related in complex ways for Ravaisson. The first point to make here is that not all habits involve or derive from reflective

\footnotetext{
${ }^{3}$ If they were entirely instinctive, no intelligence would be involved on Ravaisson's account.
} 
thought. Many 'passive' habits, for instance, come into existence below the thresholds of consciousness. Additionally, when reflective thought is involved, habit and deliberation are entangled in an ebb and flow like pattern. Many 'active' habits are post-reflective in the sense that voluntary movements have become effortless and embodied, and this opens up possibilities for undertaking other activities, which may or may not be animated by reflective thought, as well as for spontaneity, adaptation and creativity - think of a very experienced cyclist who can engage in a conversation with a fellow cyclist whilst also navigating heavy traffic. There are, of course, limits to the capacity to do multiple things at once but the point is that a habit opens up the possibility of gradual change of actions from within. Habit as prereflective embodied intelligence allows for recombination whereby gradually new elements become interwoven and integrated in action and behaviour. This means that behaviour can be altered significantly over time but in ways that defy the identification of clear steps or moments of change. Consider, as an example of such gradual change, the way in which the mobile phone has become integrated into the ways in which many of us plan face-to-face contact with others. The habit of planning meetings and activities some time in advance in a single communication episode (e.g. a call) has to some extent morphed into 'microcoordination' (Ling, 2004): many of us now iteratively arrange a meeting with a friend or drew up a schedule through a series of calls, e-mails, text messages, etc. that are distributed across space and time.

A further strength of Ravaisson's approach is that it applies to different types of habit, including motor habits like playing the piano or navigating busy traffic on a bike and habits with strong moral overtones. His double law is applicable to both habits that are widely considered undesirable, such as alcoholism, and those that can be considered virtuous (which brings us back to Aristotle). All of these can become second nature:

\footnotetext{
"Virtue is first of all an effort and wearisome: it becomes something attractive and a pleasure only through practice, as a desire that forgets itself or that is unaware of itself, and gradually it draws near to the holiness of innocence" (Ravaisson, 2008[1838], page 69).
} 


\section{2| Dewey on Habit}

There are many commonalities and overlaps between Ravaisson's essay and the work of American pragmatist John Dewey, and especially his 1922 book Human Nature and Conduct. Yet it should be appreciated that Ravaisson and Dewey engage with habit from different angles and with different purposes, which means that there are also significant differences between these authors. ${ }^{4}$ Points of convergence are, for instance, that both think of habit as a tendency and disposition that is active and self-perpetuating, as more than repetition and automaticity, as separate from instinct, and as a means to overcome the Cartesian body and mind split and privileging of the latter.

Nonetheless, drawing on Dewey helps us to extend and in certain ways radicalise the understanding of habit that can be obtained from Ravaisson. A number of points stand out in this respect. Firstly, Dewey (1922) uses not only the term tendency in relation to habit, but also predisposition, ability and art formed though past experience. Habit, then, is an active force whereby the outcomes - that is, the actions - are open-ended rather than pre-given or pre-determined: repetition of past acts and "enslavement to old ruts" (1922, page 66) are not the essence of habits. All habits involve "setting up a mechanism of action, physiologically ingrained, which operates "spontaneously", automatically, whenever the cue is given. But mechanization is not of necessity all there is to habit" (Dewey, 1922, page 70), for habits also enable. While some habits are characterised primarily by routine and mechanism, many are imbued with intelligence, grace and soul and enable creativity and novelty. The piano virtuoso is a case in point, but so is the cyclist who skilfully navigates urban traffic. The parallels with Ravaisson are obvious.

A second point is that from Dewey - more explicitly than from Ravaisson - we can derive that habits are decentred and distributed. They are more-than-individual and emerge from the

\footnotetext{
${ }^{4}$ For Ravaisson habit provided a philosophical method to appreciate and understand nature's continuity and unity. Dewey, in contrast, was interested in habit because he wanted to contribute to social reform by resituating morals and morality in human nature and people's ordinary dealings with their environments.
} 
relations between person and environment: "habits are ways of using and incorporating" objects, tools, the physical surroundings, other human beings in which all these have their "say as surely as the former" (Dewey, 1922, page 15). We can read Dewey as indicating that habits are not contracted by an individual as a centred and sovereign Cartesian subject but belong to and hold together a body-mind-world assemblage (Venn, 2010). This is a collective that exceeds the individual as conventionally understood. It is an ensemble in which organs (including the brain), senses, techniques, procedures, skills, objects, fellow human beings, and so on act as a single system. Understanding habit as belonging to body-mind-world assemblages resonates closely with the perspective on action and decision-making advanced by Thrift (2008a) and others (Dewsbury, 2011; McCormack and Schwanen, 2011).

Thirdly, Dewey emphasises that habits that once have come into being endure below the surface of visibility as latent forces; habits once contracted by a body-mind-world assemblage persist when they are not overt and can be re-activated at a later point in time. Training people at a young age so that they acquire certain habits early onwards thus means that people may take those habits with them for a long time in their life (at least until their corporeal bodies' abilities change because of bodily ageing, illness and so on). In this regard Dewey concurs with William James (1890) for whom the continuity of training from a young age onwards was critical to the formation of moral habits: "we must make automatic and habitual, as early as possible, as many useful actions as we can, and guard against the growing into ways that are likely to be disadvantageous to us, as we should guard against the plague" (page 122).

Fourthly, Dewey is more radical than Ravaisson with regard to the relations between habit and reflective thought. In keeping with other pragmatist philosophers, he held the view that habits are ontologically primordial to reflective thought and emotions, and that deliberation is not innate but the consequence of habits in operation. Rather provokingly he wrote that:

\footnotetext{
"[t]he act must come before the thought, and a habit before the ability to evoke the thought at will. Ordinary psychology reverses the actual state of affairs" (Dewey, 1922:30).
} 
Dewey thus differs from Ravaisson not only in arguing that the mind is social through and through, but also by according less importance to conscious thought.

Finally, Dewey is more explicit about how different habits interact with one another and sees conflicts between habits as a key source of social change. To elaborate this point we need to introduce the distinction Dewey makes between personal habits and customs or institutions collective habits held by wider social groups. For Dewey personal habits emerge under conditions set by prior customs - he frequently invokes the example of the infant whose "inchoate and scattered impulses" can only develop into habits and independent action by gathering "nutrition from customs" (1922, page 94). He also contends that clashes among personal habits and between personal habits and customs release impulse activity (which is inherited rather than learned) in individuals, through which their habits become reorganised. In this reorganisation process reflective deliberation as an ability emerges, and this may subsequently trigger a reorganisation of institutions.

Note that, for Dewey, reflective thought does not come 'naturally' from within and prior to habit - as in the previously discussed psychological approaches to habit - but emerges through interruptions from outside (Bissell, 2012) that challenge habit. Another key idea here is that customs or institutions in which people, artefacts, infrastructures, ideas, and so on are assembled together, influence habits rather than behaviour, intentions or beliefs. It is through the remoulding of existing and creation of new habits that the latter are affected. Dewey suggests, in other words, that changes to individuals' habits as embodied dispositions and abilities to act in particular ways are fundamental to the materialisation of behaviour change. This is not to say that attitudes, beliefs and so on are unimportant, but that the existence of habits that are congruent with and facilitate the desired behaviour takes temporal and ontological precedence over them.

\section{3| Summary and development}


Based on Ravaisson, Dewey and others, we can understand habits as propulsive and generative tendencies rather than as behaviours. They are therefore open-ended and nondeterministic. Additionally, habits are neither individualistic nor primarily a cognitive phenomenon originating in the functioning of the brain. This is not to suggest that the brain is unimportant, but rather to argue for a less hierarchical, more distributed perspective on the organisation of behaviour. The brain is here understood as being "as much a transmitter and receiver as a fixed node [whose] power comes from its ability to forage and monitor and then communicate that foraging and monitoring" (Thrift, 2008a, page 84), as one agent among others. The brain is the mediator rather than originator or container of habits (Bergson, 1911[1907]; Middleton and Brown, 2005).

More generally, a habit is an emergent property of a body-mind-world assemblage something that is fabricated out and ties together the fluid and continuously changing ensembles of limbs, muscles, sensory organs, the brain, neurochemical processes within the corporeal body, artefacts (including transport technologies), infrastructures, bodies of other human beings, rules, procedures, ideas, norms and other agents encountered as part of the flows and rhythms of everyday life. In simpler terms, a car habit is that what makes it possible for car, driver, road, signs, passengers, traffic rules to merge into a seemingly effortless whole and what underpins the routine use of cars to access places. And the car habit of the body-mind-world assemblage involving one particular driver interpenetrates and cuts across the habits of assemblages centred on other drivers. The totality of these interlocking habits can be understood as a custom in Deweyian sense. It should be recognised that the habits that emerge around two specific corporeal bodies or persons differ from each other. This is among others because corporeal bodies are differentiated. Each body is imbued with singular abilities and disabilities - themselves partial effects of that body's interactions with the settings and situations of everyday life (Schillmeier, 2008; Schwanen et al., 2012) - and these shape (and are shaped by) the habits and actions of body-mind-world assemblages. 
Understood along these lines, habit weaves together mechanism and creativity, repetition and difference, structure and agency, the social and the cognitive. Dualistic oppositions are generally to be avoided because of the simplifications they imply and the favouring of one pole over the other they often entail; however, table 1 outlines some of the differences between the mainstream view and the perspective outlined above for heuristic purposes. It is intended to sensitise readers to the more salient differences.

Table 1| Different understandings of habit

\begin{tabular}{l|l}
\hline Prevailing understandings (in transport research) & Our understanding \\
\hline $\begin{array}{l}\text { Habit as a behaviour that is automatically cued } \\
\text { Emphasis on repetition; automaticity; stability }\end{array}$ & $\begin{array}{l}\text { Habit as a tendency brought about through repetition } \\
\text { Emphasis on repetition as well as (gradual) alteration } \\
\text { and spontaneity; stability and change } \\
\text { A consequence of the coming into existence of } \\
\text { relatively stable body-mind-world assemblages } \\
\text { A consequence of how cognition and the mind } \\
\text { function }\end{array}$ \\
$\begin{array}{l}\text { Individualistic: habit as contracted and held by an } \\
\text { individual }\end{array}$ & $\begin{array}{l}\text { body-mind-world assemblage } \\
\text { Habit is linked linked to society and community }\end{array}$ \\
No direct links of habit with morality and ethics & Habit as the basis for morality and ethics
\end{tabular}

\section{4| Governing habits}

Thinking habit as just discussed has implications for behaviour change in passenger transport. Whilst attempts to defrost carbon-intensive (travel) habits are a necessary component of policy interventions aiming to achieve large-scale behaviour change, transport policy should not simply work against but with habits and in ways that exceed the recommendations that follow from behavioural economics (cf. Dolan et al., 2010).

\section{1| Displacing carbon-intensive habits}

Had they lived nowadays, both Ravaisson and Dewey would have been sceptical of attempts to modify carbon-intensive travel habits that evolve exclusively or even primarily around information provision and attempts to reconfigure an individual's beliefs or values. As 
described above, Ravaisson emphasised how habit reaches deep down into the body, to the extent that they become propulsive tendencies and second nature. And while reflection and will can be powerful forces, they are often no match for the deep-seated tendencies people have acquired long ago. On the other hand, Ravaisson also argued that habits are reversible, even though this takes time and is a slow and sometimes even painful process requiring patience and persistence (Carlisle, 2010). Discussing attempts to correct a person's bad posture and an alcoholic's drinking behaviour, Dewey made a similar point whilst also pointing towards routes for durable habit change:

\footnotetext{
"[c]onditions have been formed for producing a bad result, and the bad result will occur as long as those conditions exist. They can no more be dismissed by a direct effort of will than the conditions which create drought can be dispelled by whistling for wind. It is as reasonable to expect a fire to go out when it is ordered to stop burning as to suppose that a man [sic] can stand straight in consequence of a direct action of thought and desire. The fire can be put out only by changing objective conditions; it is the same with rectification of bad posture" (Dewey, 1922, page 29).
}

For him, attempts to "transfer command [over the body] inside character and mind" (page 30) are unlikely to be successful unless the habits on which deliberation is premised are reconfigured. This requires changes to 'objective conditions', which are not - or rather not only - infrastructures or pricing structures as most travel behaviour analysts would have it but the customs and institutions that have shaped the habits of body-mind-world assemblages. Adopting a Deweyian lens allows us to see that interventions that consist only in changes to the material infrastructures and prices of prices may be less effective in reconfiguring habits than mainstream transport thinking tends to suggest.

Dewey's discussion of customs and institutions as drivers of changing habits is fairly unspecific. We take him to imply that many different rather than one or some of the elements woven together in habit as a distributed phenomenon need to be modified for widespread behaviour change to materialise. Carbon-intensive travel habits are more likely to be 
displaced if the behaviour change agenda is accompanied by, and embedded in, systemic change in which the socio-technical system of automobility - the conglomerate of technologies, infrastructures, regulations, knowledges, user practices, cultural preferences that has developed around the car (Urry, 2004; Geels, this issue) - is durably reconfigured. The Deweyian logic is as follows: reconfiguration of the system of automobility into one that is dominated by collective transport and/or active transport means that the likelihood of strong clashes between (changed) customs and the car habits held by body-mind-world assemblages is maximised. These clashes may then "foster antagonistic impulses and form contrary dispositions" (Dewey, 1922, page 129) in those assemblages and eventually trigger habit adaptation.

This adaptation should, however, not to be considered a top-down process in which the bodymind-world centred on a particular person is a passive receptacle and changing customs automatically translate straightforwardly into habit change. Persons may persist in their habits, for instance because their Ravaissonian receptivity - ability to undergo change from outside - has been diminished too much and carbon-intensive travel has become well-nigh instinctive, or out of resistance to governmental attempts by public authorities or other actors. More generally, how and to what degree habits are reconfigured depends on the specific interactions between the elements in a body-mind-world assemblage, the particulars of the embodied intelligence that has developed, and the activity/travel schedules to be fulfilled. At an aggregate level, habit change is likely to be characterised by complex combinations of similarity and difference across body-mind-world assemblages.

All of this implies that behaviour change towards non-car based mobility necessitates a focus on a broad range of stakeholders beyond individuals as users of transport systems, including the transport and retail industry, politicians, consultants, the media, lobby organisations and others with the power to shape customs. If - as in most psychological studies of travel habits and in some policy discourses - the aim is to achieve a shift away from car use, then concessionary fares for public transport or the provision of (individually tailored) information about travel alternatives need to be embedded in much wider programmes of intervention. 
These include changes to the material infrastructures for alternative means of transport and to the built environment and separation of origins and destinations but much more is to be done. For one, the cultural meanings and affective atmospheres associated with cars need to be reconfigured, and popular connotations of cars with freedom, power, control need to be challenged. This can be done, among others, by exposing the affective politics of car advertising, which seeks to rework people's gut feelings below the threshold of consciousness (Connolly, 2002; Thrift, 2007) in ways that override moral discourses about the 'unfreedoms' (Freudendal-Pedersen, 2009) tied to fossil fuel-powered cars and that can be considered unfair. Those unfreedoms include the ways in which widespread use of fossil fuel-powered cars often traps people in harried and fragmented lifestyles, in particular social expectations and in dependencies on an increasingly depleted natural resource, as well as the relative immobilisation of people who for some reason do not have access to a car.

Wider customs bound up with neoliberal capitalism and conducive to car ownership and use, such as the valorisation of consumerism and private ownership, would need to be challenged too. And more than 'green-washing' and incremental change is required from the technoindustrial complex centred on car production, sales and trade to make widespread, durable habit change more likely. It is not enough to on the one hand emphasise the environmental performance and benefits of certain car types in communications with potential users whilst on the other facilitate the deepening of Ravaisson's embodied intelligence between driver and car through comfort-enhancing and affective techniques such as the incorporation of airconditioning or, more recently, ICT facilities and the designing of fossil-fuel dependent cars' interiors using state-of-the art ergonomic knowledges (cf. Thrift, 2007).

We do not suggest that governments ought to orchestrate the reconfiguration of carbonintensive transport systems in a top-down manner as all-power conductors. This would be neither desirable nor possible for reasons that differ across countries and regions within these. Key factors would nonetheless include in many places the popularity of neoliberal governmental rationalities, the need for financial austerity, and/or inadequate governmental institutions. Social movements probably will have to play an important role in reconfiguring 
high-carbon transport systems and customs (cf. Geels and Verhees, 2011). Governments can nonetheless do many things. Apart from ensuring that accessibility by low-carbon transport modes is adequate and carbon-intensive transport is not underpriced, they can try to enrol as many stakeholders as possible into and facilitate transitions towards low-carbon mobility systems in ways that echo and resonate with the transition management approach (Kemp et al., 2007; Loorbach, 2010). They also need to make sure the signals they send out to other stakeholders become much more coherent and internally consistent; it is insufficient to profess to belief in low-carbon and non-car forms of mobility and simultaneously build new roads to stimulate the economy.

\section{2| Nourishing low-carbon habits}

Significant changes to the socio-technical system may, however, not be enough to durably reconfigure travel habits. Equally important is the availability of alternative habits. Yet, the creation of new habits deemed desirable has received rather modest attention in the transport-related literature about behaviour change (see Verplanken and Wood, 2006 for a similar argument with regard to other policy domains). Following Dewey once more, we can say that those alternative habits need not be overt; they can be latent, for instance because they have been formed earlier in the life-course. Changes to the socio-technical systems of high-carbon transport may then re-activate embodied intelligences developed earlier. With regard to everyday passenger transport, this means that policy and governance should not simply seek to reconfigure the system of automobility but also actively stimulate the development of certain capacities and Ravaissonian movements in people's bodies from a young age onwards. Ravaisson (2008[1838]), Dewey (1922) and James (1890) all point to education of the young as crucial to the reshaping of established habits and customs.

The literature about travel behaviour in transport studies and about mobilities in (cultural) geography and sociology provides surprisingly few empirical studies of the contribution that habits previously contracted during the life-course can make to behaviour change; this constitutes a fertile avenue for further research. Nonetheless, the literature about driving 
reduction and cessation in later life provides some useful indications. It has been shown that, while older people often experience driving cessation as a loss, those who were used to travelling on public transport or with modes other than the car in general earlier in the lifecourse adapted more easily to life after the car (Schwanen and Páez, 2010). Weinberger and Goetzke's (2010) study of car ownership in conjunction with residential relocation is also relevant. These authors show old habits to be transferred across residential environments: individuals moving from a central city to the suburbs owned fewer cars than other suburbanites and people who had moved from the suburbs to the central city owned more cars than other urbanites. Further, Emond and Handy (2012) show that adolescents in Davis, California are more likely to cycle to school if their parents are supportive of cycling.

The limited evidence notwithstanding, the training of bodies in using non car-based transport early in the life-course seems important, in particular for cycling. This can also be illustrated with reference to the cycling culture in the Netherlands. Local policies of cycling infrastructure provision (bike lanes, bike sheds, traffic calming) and national-level traffic laws have been important in bringing about this culture (Pucher and Buehler, 2008) but at least as important are the myriad formal and informal techniques through which learning to cycle is an integral part of growing up in Dutch society: many pre-school children transition smoothly from a tricycle or step to a small bicycle, a 'real' bike is a common birthday present around the time a child enters elementary school, and in most elementary schools children aged 11 are expected to take part in the 'traffic exam' in which they have to cycle a route with intersections and other potentially complex traffic situations completely independently. Echoing James' (1890) we suggest that crucial to cycling habits in the Netherlands is the continuity of techniques and the positive reinforcement they afford over the early stages of the life-course. This continuity of formal and informal customs comes with three benefits. Not only do children acquire the competence and confidence to cycle without supervision, they also develop the Ravaissonian spontaneity and embodied intelligence through which they negotiate complex traffic situations in ways that are neither reflective nor instinctive. ${ }^{5}$

\footnotetext{
${ }^{5}$ This embodied intelligence is not separate from but envelopes and draws on such infrastructural elements as dedicated bicycle lanes, road signs and toucan crossings.
} 
Moreover, they develop a disposition towards cycling that guides them in a nondeterministic fashion towards 'choosing' to cycle for certain types of trip. The embodied intelligence associated with walking is quite different from that for cycling (Middleton, 2011), but we can nonetheless speculate that some of the benefits of continuous cycling training spill over to walking, helping to generate body-mind-world assemblages held together by strong walking habits.

A more ambiguous example of generating such assemblages is the 'Walking School Bus' (WBS) whereby parents or other adults walk children to/from school in groups along fixed routes and based on timetables like school buses. According to research in New Zealand, WSBs come with a number of health and community benefits (Kingham and Ussher, 2007; Collins and Kearns, 2010). However, not only are these benefits unequally distributed along ethnic and class lines with more privileged children benefiting the most (Collins and Kearns, 2005); the very idea of the WBS is built on discourses that position children as vulnerable and incompetent users of road spaces (cf. Valentine, 1997). It is questionable, therefore, that WSBs enable children to learn the full range of embodied capacities of participating in traffic on foot independently and confidently. More generally, it is not inconceivable that safetyrelated discourses - which are particularly strong in Anglo-Saxon countries - inhibit the formation of durable walking and cycling habits from a young age onwards. Here too, changes in customs are in order.

In short, education via learning-by-doing is a key policy strategy to nourish the development of low-carbon travel habits. On the basis of Ravaisson's general law of habit, we believe that the effects of education via learning by doing will be maximised if such education is coupled to attempts to trigger the systemic changes of car-oriented customs described in section 4.1. After all, the development of Ravaissonian spontaneity with regard to low-carbon transport needs to be complemented with decreasing exposure to signals from carbon-intensive transport systems, so that initial receptivity - the ability of those systems to (re)recruit subjects - is lowered. 


\section{3| Capitalising on spontaneity within carbon-intensive habits}

This strategy of amounts to exploiting the transformative potential of existing (carbonintensive) travel habits, which Ravaisson highlights. This most emphatically is not a plea for laissez faire. It is about trying to create the conditions conducive to spontaneity and about complicating the notion of behaviour change in passenger transport: too often there is a naïve assumption that trips by fossil fuel-powered cars can be substituted when distances are rather short, accessibility by public transport, walking or cycling are adequate, and so on. This, however, misses the point that, given the current system of automobility (Urry, 2004), the car is in many instances the only realistic option for people to perform socially desired subjectivities in advanced liberal democracies. ${ }^{6}$ Whilst this may change with a wholesome shift in customs, there will still be situations in which the unique affordances of individualised motorised transport will be indispensible for local trips and geographical contexts where private cars will be the dominant form of transport. For situations, such as the school run by parents working long hours that conflict with school times, for people like independently living elderly with declining physical health, or in places where sprawl is so vast that retrofitting and brownfield development are unlikely to make much of a difference, a strategy of incremental change built around spontaneity in habits is perhaps most sensible.

From a policy perspective, capitalising on spontaneity and thus the open-endedness of habits is tricky: 'subtle change from within' is rather difficult to direct or steer (as the aforementioned example of the changing customs associated with the rapid diffusion of mobile phone through societies suggests). However, the distributed character of habits provides opportunities to stimulate spontaneity. In the case of automobility, one set of opportunities evolves around the vehicle, which at some point in time needs to be replaced. ${ }^{7}$

\footnotetext{
${ }^{6}$ See, for instance the (limited) literature on the school run as an embodied practice by mothers/parents (Jain et al., 201), on the lived experience of travelling among independently living older people (Schwanen et al., 2012), and on car use among low-income households (Lucas, 2011).

7 From the perspectives of vehicle production and infrastructure a shift from fossil fuel-powered to electric vehicles clearly constitutes a systemic change but this is less so from the point of view of citizen-consumers, whose habits and practices will change but only slightly compared to situations where non-car modes dominate personal transport systems.
} 
One governmental strategy could very well be to conventionalise electric vehicles (EVs) and similar low-emission vehicles, as this may stimulate the seamless weaving of low-carbon technologies into existing habits. It should be appreciated that such vehicle replacement entails at least some change to car habits: not only are there practical issues concerning range and recharging; the affective experience of driving also changes given that EVs tend to be quieter, accelerate less quickly and 'feel' differently to conventional cars.

With regard to conventionalising EVs, it seems important to both culturally frame them in particular ways and to facilitate certain habits. Cultural framing - animating (new) artefacts with certain values and ideas in texts, ads, media reports and so on - matters because it codetermines the cultural legitimacy and the success of new technologies (Pinch and Bijker, 1984; Geels and Verhees, 2011). From a habit perspective, it makes sense to position EVs in Western countries not so much - or at least not simply - as a novelty and a hallmark of technological progress with decarbonisation benefits. EVs should rather be framed as fashionable and as easy, reliable and riskless in everyday use. Such framings would be important for generating desire or appetite for EVs and to stimulate adoption (and could be complemented with other techniques, such as financial incentives).

Equally if not more important is the enhancement of Ravaissonian spontaneity in habits. At the practical level, driving an EV must become a triviality requiring little or no reflective thought: the supporting infrastructures must sink into the wider assemblage of background infrastructures that support everyday life as quickly as possible. There is after all "no more miserable human being than one in whom [driving and recharging an EV] are subjects of express volitional deliberation" (James, 1890, page 122). Policymakers, engineers and researchers should not only consider the number of spatial distribution of recharging facilities, but also the electronic payment systems, radio frequency identification (RFID) technologies, rules and other elements that shape the ease and comfort of driving an EV. All these elements are active constituents of low-carbon car habits, and may help to both enrol people into EV use and prevent them from reverting back to fossil fuel-powered cars. 


\section{5| Final remarks}

In this paper we have begun to sketch a affirmative approach to (travel) habits drawing on the Aristotelian philosophies of Ravaisson and Dewey, and outlined a number of consequences for the behaviour change agenda. Most emphatically our aim has not been to reject theories from psychology or the policy interventions that can be derived from them. However, we do think that the understandings of habit that prevail among psychologists and transport scholars are too restrictive and that a more comprehensive and systemic approach to the reconfiguration of habits and to behaviour change is in order. This approach would:

- Give as much attention to habit formation and endogenous renewal as to habit breaking;

- Avoid privileging cognition and to a lesser degree infrastructure over bodily capacities and tendencies, and focus on body, mind and world in equal measure;

- Move beyond a focus on one or a few instruments (e.g., information provision or reduced fares) and transcend the hard/soft and behaviour/technology dualisms;

- Also target the stakeholders beyond 'users' of transport systems - transport industry, retailers and advertising companies, the media, lobby groups, employers and nontransport government agencies and departments - whose practices contribute to the collective sense-making and normative coding of different forms of mobility. The informational, financial, symbolic or affective signals regarding which travel practices are desirable from across government agencies to citizens and other stakeholders should be made more coherent for extended periods of time.

Nonetheless, the affirmative approach to habit we have begun to outline is in need of further development. Several avenues for further work can be identified. The gendered, classed, raced, aged nature of habits needs to be elaborated. Pykett (2012) criticises dominant psychological accounts of behaviour change (i.e. attitude theories and behavioural economics) for obscuring the social and environmental dimensions of rationality, consciousness, decision-making and habits. Specifically with regard to gender, she argues that soft paternalist policies may be at best ineffective and at worst perpetuate existing 
inequalities because they overlook people's embodied engagements with the world and responsibilities towards others - phenomena that profoundly shape the gendering of travel practices (Hanson, 2010). Given its emphasis on body-mind-world assemblages, the approach we developed could address Pykett's and others' concerns by drawing on the work of Bourdieu and such feminist thinkers as Iris Young.

Given that passenger transport must be decarbonised sooner rather than later, reconceptualising (travel) habits needs to be paralleled by practical experimentation. Research is required that uses participatory and other methods in which novel, creative ways of reconfiguring carbon-intensive travel habits are constructed and tested with citizens and other stakeholders. We believe that habits as capacities rather than as readily observable outward performances or behaviours can be explored through auto-ethnographies performed by research subjects trained to become co-researchers, and through video-diaries that are made by individuals and subsequently discussed collectively by the researcher, the makers and others who know them and can comment and reflect on the habits considered. Methods whereby subjects have to engage in role play and research is combined with performance arts (drama, dance) can also open up habits for subsequent reflective discussions. Whatever the format, it is imperative that the traditional, positivist distribution of expertise with academics doing research about subjects and their habits is traded for more complex, less hierarchical relations between researchers and the researched. Transport geographers - and transport scholars more generally - have been slow to experiment with performativeparticipatory methods but could benefit from previous work in non-representational and feminist geography in this regard (e.g., McCormack, 2002; Latham, 2003; Gibson-Graham, 2006; Lea, 2009). Insights obtained in this way will help us to better understand the mechanisms, strategies and techniques through which current carbon-intensive travel habits can be changed into durable low-carbon customs.

\section{Acknowledgements}


The research in this paper has been made possible by grant RES-584-28-0002, UKTRC: Climate Change, Energy and Transport by the ESRC. We are grateful to the reviewers for their helpful comments on an earlier version of the manuscript.

\section{References}

Aarts, H., Dijksterhuis, A., 2000. The automatic activation of goal-directed behaviour: the case of travel habit. Journal of Environmental Psychology 20(1), 75-82.

Ajzen, I. 1991. The theory of planned behavior. Organizational Behavior and Human Decision Processes 50(2), 179-211.

Anable, J., 2005. 'Complacent car addicts' or 'aspiring environmentalists'? Identifying travel behaviour segments using attitude theory. Transport Policy 12(1), 65-78.

Anable, J., Brand, C., Tran, M., Eyre, N., 2012. Modeling transport energy demand: a sociotechnical approach. Energy Policy 41, 125-138.

Aristotle, 1980[n.d.]. The Nichomachean Ethics. Translated by David Ross. Oxford University Press, Oxford.

Bagley, M.N., Mokhtarian, P.L., 2002. The impact of residential neighborhood type on travel behavior: A structural equations modeling approach. Annals of Regional Science 36, 279-297.

Bamberg, S., 2002. Effects of implementation intentions on the actual performance of new environmentally friendly behaviours - results of two field experiments. Journal of Environmental Psychology, 22, 399-411.

Bamberg, S., Schmidt, P., 2003. Incentives, morality, or habit? Predicting students' car use for university routes with the models of Ajzen, Schwartz and Triandis. Environment and Behaviour $35(2), 264-285$.

Bamberg, S., Fujii, S., Friman, M., Gärling, T., 2011. Behaviour theory and soft transport policy measures. Transport Policy 18(1), 228-235.

Banister, D. 2008. The sustainable mobility paradigm. Transport Policy 15(1), 73-80.

Bergson, H., 1911[1907]. Creative Evolution. Henry Holt \& Co., Lanham, MD.

Bissell, D., 2012. Agitating the powers of habit: towards a volatile politics of thought. Theory \& Event 15(1), no pagination.

Bissell, D., 2011. Thinking habits for uncertain subjects: movement, stillness, susceptibility. Environment and Planning A 43, 2649-2665.

Boarnet, M.G. 2010. Planning, climate change, and transportation: Thoughts on policy analysis. Transportation Research Part A: Policy and Practice 44(8), 587-595.

Bonsall, P., 2009. Do we know whether personal travel planning really works? Transport Policy $16(6), 306-314$.

Brög, W., Erl, E., Ker, I., Wall, R., 2009. Evaluation of voluntary travel behaviour change: experiences from three continents. Transport Policy 16(6), 281-292.

Burkitt, I., 2002. Technologies of the self: habitus and capacities. Journal of the Theory of Social Behaviour 32(2), 219-237. 
Cairns, S., Sloman, L., Newson, C., Anable, J., Kirkbride, A., Goodwin, P., 2008. Smarter choices: assessing the potential to achieve traffic reduction using 'soft measures'. Transport Reviews 28(5), 593-618.

Carlisle, C., 2010. Between freedom and necessity: Félix Ravaisson on habit and the moral life. Inquiry 53(2), 123-145.

Carlisle, C., Sinclair, M., 2008a. Editor's introduction. In: Carlisle, C., Sinclair, M. (Eds.), Félix Ravaisson - Of Habit, pp. 1-21. Continuum, London.

Carlisle, C., Sinclair, M., 2008b. Editor's commentary. In: Carlisle, C., Sinclair, M. (Eds.), Félix Ravaisson - Of Habit, pp. 78-114. Continuum, London.

Collins, D.C.A., Kearns, R.A., 2005. Geographies of inequality: Child pedestrian injury and walking school buses in Auckland, New Zealand. Social Science \& Medicine 60(1), 61-69.

Collins, D., Kearns, R.A., 2010. Walking school buses in the Auckland region. Transport Policy $17(1), 1-8$.

Connolly, W.E. 2002. Neuropolitics: Thinking, Culture, Speed. University of Minnesota Press, Minneapolis, MN.

Damasio, A.R., 1994. Descartes' Error: Emotion, Reason, and the Human Brain. Putnam, New York.

Darnton, A., Verplanken, B., White, P., Whitmarsh, L., 2011. Habits, Routines and Sustainable Lifestyles: A summary report to the Department for Environment, Food and Rural Affairs, AD Research \& Analysis, London.

DEFRA, 2008. A Framework for Pro-Environmental Behaviours. Department for Environment, Food and Rural Affairs, London.

Dewey, J., 1922. Human Nature and Conduct: An Introduction to Social Psychology. Henry Holt and Company, New York.

Dewsbury, J.D., 2011. The Deleuze-Guattarian assemblage: plastic habits. Area 43(2), 148-153.

DfT, 2011. Creating Growth, Cutting Carbon: Making Sustainable Local Transport Happen. Department for Transport, London.

Dobson, R., Dunbar, F., Smith, C.J., Reibstein, D., Lovelock, C., 1978. Structural models for the analysis of traveler attitude-behavior relationships. Transportation 7(4), 351-363.

Dolan, P., Hallsworth, M., Halpern, D., King, D., Vlaev, I., 2010. MINDSPACE: Influencing Behaviour through Public Policy. Cabinet Office and Institute for Government, London.

Emond, C.R., Handy, S.L., 2012. Factors associated with bicycling to high school: insights from Davis, CA. Journal of Transport Geography 20, 71-79.

Eriksson, L., Garvil, J., Nordlund, A.M., 2008. Interrupting habitual car use: the importance of car habit strength and moral activation for personal car use reduction. Transportation Research F: Traffic and Psychology 11(1), 10-23.

Ewing, R., Bartholomew, K., Winkelman, S., Walters, J., Anderson, G., 2008. Urban development and climate change. Journal of Urbanism: International Research on Placemaking and Urban Sustainability 1(3), 201-216.

Freudendal-Pedersen, M., 2009. Mobility in Daily Life: Between Freedom and Unfreedom. Ashgate, Aldershot.

Fujii, S., Garling, T., Kitamura, R., 2001. Changes in drivers' perceptions and use of public transport during a freeway closure: effects of temporary structural change on cooperation in a 
real-life social dilemma. Environment and Behavior 33(6), 796-808.

Fujii, S., Kitamura, R., 2003. What does a one-month free bus ticket do to habitual drivers? An experimental analysis of habit and attitude change. Transportation 30(1), 81-95.

Gardner, B., 2009. Modelling motivation and habit in stable travel mode contexts. Transportation Research Part F: Traffic Psychology and Behaviour 12(1), 68-76.

Gärling, T., Fujii, S., Boe, O., 2001. Empirical tests of a model of determinants of script-based driving choice. Transportation Research Part F: Traffic Psychology and Behaviour 4(2), 89-102.

Gärling, T., Axhausen, K.W., 2003. Introduction: habitual travel choice. Transportation 30(1) 1-11.

Gatersleben, B., Vlek, C., 1998. Household consumption, quality of life, and environmental impacts: a psychological perspective and empirical study. In: Noorman, K.J., Schoot Uiterkamp, T. (Eds.), Green Households? Domestic Consumers, Environment, and Sustainability. Earthscan, London, pp. 141-183.

Geels, F.W., this issue. Understanding the dynamics of low-carbon transitions in transport systems: a socio-technical approach and multi-level perspective. Journal of Transport Geography.

Geels, F.W., Verhees, B., 2011. Cultural legitimacy and framing struggles in innovation journeys: a cultural-performative perspective and a case study of Dutch nuclear energy (1945-1986). Technological Forecasting \& Social Change 78(6), 910-930.

Gibson-Graham, J.K., 2006. A Postcapitalist Politics. University of Minnesota Press, Minneapolis, MN.

Gollwitzer, P.M., 1999. Implementation intentions: strong effects of simple plans. American Psychologist, 54, 493-503.

Golob, T.F., 2001. Joint models of attitudes and behavior in evaluation of the San Diego I-15 congestion pricing project. Transportation Research A: Policy and Practice 35(6), 495-514.

Golob, T.F., Horowitz, A.D., Wachs, M., 1979. Attitude-behaviour relationships in travel-demand modelling. In: Hensher, D.A., Stopher, P.R. (Eds.), Behavioural Travel Modelling, pp. 739-757. Croom Helm, London.

Halpern, D., Bates, C., Mulgan, G., Aldridge, S., Beales, G., Heathfield, A., 2004. Personal Responsibility and Changing Behaviour: The State of Knowledge and Its Implications for Public Policy. Cabinet's Office, London.

Hanson, S., 2010. Gender and mobility: new approaches for informing sustainability. Gender, Place \& Culture 17(1), 5-23.

Haustein, S., Hunecke, M., 2007. Reduced use of environmentally friendly modes of transportation caused by perceived mobility necessities: an extension of the Theory of Planned Behavior. Journal of Applied Social Psychology 37(8), 1856-1883.

Hunecke, M., Haustein, S., Grischkat, S., Böhler, S., 2007. Psychological, sociodemographic, and infrastructural factors as determinants of ecological impact caused by mobility behavior. Journal of Environmental Psychology 27(4), 277-292.

Jain, J., Line, T., Lyons, G., 2011. A troublesome transport challenge? Working round the schoolrun. Journal of Transport Geography 19(6), 1608-1615

James, W., 1890. The Principles of Psychology, Volume I. Henry Holt \& Co., Lanham, MD

Jones, R., Pykett, J., Whitehead, M., 2011. Governing temptation: changing behaviour in an age of libertarian paternalism. Progress in Human Geography 35(4), 483-501. 
Kemp, R., Loorbach, D., Rotmans, J., 2007. Transition management as a model for managing processes of co-evolution towards sustainable development. International Journal of Sustainable Development \& World Ecology 14(1), 78-91.

Kingham, S., Ussher, S., 2007. An assessment of the benefits of the walking school bus in Christchurch, New Zealand. Transportation Research Part A: Planning and Practice 41(6), 502-510.

Klöckner, C.A., Blöbaum, A., 2010. A comprehensive action determination model: Toward a broader understanding of ecological behaviour using the example of travel mode choice. Journal of Environmental Psychology 30(4), 574-586.

Latham, A., 2003. Research, performance, and doing human geography: some reflections on the diary-photograph, diary-interview method. Environment and Planning A 35(11), 1993-2017.

Lea, J., 2009. Becoming skilled: The cultural and corporeal geographies of teaching and learning Thai Yoga massage. Geoforum 40(3), 465-474.

Ling, R., 2004. The Mobile Connection: The Cell Phone's Impact on Society. Elsevier, Amsterdam.

Loorbach, D., 2010. Transition management for sustainable development: a prescriptive, complexity-based governance framework. Governance 23(1), 161-183.

Lucas, K., 2011. Driving to the breadline. In: Lucas, K., Blumenberg, E., Weinberger, R. (eds.), Auto Motives: Understanding Car Behaviours, pp. 209-224. Emerald, Bingley.

Malabou, C., 2008. Addiction and grace: Preface to Félix Ravaisson's Of Habit. In: Carlisle, C., Sinclair, M. (Eds.), Félix Ravaission - Of Habit, pp. vii-xx. Continuum, London.

Matthies, E., Kuhn, S., Klöckner, C.A., 2002. Travel mode choice of women: the result of limitation, ecological norm, or weak habit? Environment and Behavior 34(2), 163-177.

Matthies, E.A., Klöckner, C.A., Preißner, C.L., 2006. Applying a modified moral decision making model to change habitual car use: How can commitment be effective? Applied Psychology 55(1), 91-106.

McCormack, D.P., 2002. A paper with an interest in rhythm. Geoforum 33(4), 469-485.

McCormack, D.P., Schwanen, T., 2011. The space-times of decision making. Environment and Planning A 43(12), 2801-2818.

Merleau-Ponty, M., 1962[1945]. The Phenomenology of Perception. Routledge \& Kegan Paul, London.

Middleton, D.J., Brown, S.D., 2005. The Social Psychology of Experience: Studies in Remembering and Forgetting. Sage, London.

Middleton, J., 2011. "I'm on autopilot, I just follow the route": exploring the habits, routines and decision-making practices of everyday urban mobilities. Environment and Planning A 43(12), 2857-2877.

Orbell, S., Verplanken, B., 2010. The automatic component of habit in health behavior: habit as cue-contingent automaticity. Health Psychology 29(4), 374-383.

Ouellette, J.A., Wood, W., 1998. Habit and intention in everyday life: the multiple process by which past behaviour predicts future behaviour. Psychological Bulletin 124(1), 54-74.

Pinch, T.J., Bijker, W.E., 1984. The social construction of facts and artefacts: or how the sociology of science and the sociology of technology might benefit each other. Social Studies of Science 14(3), 399-441.

Polk, M., 2003. Are women potentially more accommodating than men to a sustainable transportation system in Sweden? Transportation Research D: Transport and Environment 8(2), 75-95. 
Pucher, J., Buehler, R., 2008. Making cycling irresistible: lessons from the Netherlands, Denmark and Germany. Transport Reviews 28(4), 495-528.

Pykett, J., 2012. The new maternal state: the gendered politics of governing through behaviour change. Antipode 41(1), 217-238.

Ravaisson, F., 2008[1838]. Of Habit. In: Carlisle, C., Sinclair, M. (Eds.), Félix Ravaisson - Of Habit, pp. 1-77. Continuum, London.

Reckwitz, A., 2002. Toward a theory of social practices: a development in culturalist theorizing. European Journal of Social Theory 5(2), 243-263.

Rose, N., 1996. Governing "advanced" liberal democracies. In: Barry, A., Osborne, T., Rose, N. (Eds.), Foucault and Political Reason: Liberalism, Neo-Liberalism and Rationalities of Government, pp. 37-64. UCL Press, London.

Salomon, I., Mokhtarian, P.L., 1998. What happens when mobility-inclined market segments face accessibility-enhancing policies? Transportation Research D: Transport and Environment 3(3), 129-140.

Schank, R.C., Abelson, R.P., 1977. Scripts, Plans, Goals, and Understanding. Erlbaum, Hillsdale, NJ.

Schillmeier, M., 2008. Time-spaces of in/dependence and dis/abilty. Time \& Society 17(2/3), 215231.

Schwanen, T., Banister, D., Bowling, A., 2012. Independence and mobility in later life. Geoforum, in press.

Schwanen, T., Páez, A., 2010. The mobility of older people - an introduction. Journal of Transport Geography, 18(5), 591-595.

Schwartz, S.H., 1977. Normative influences on altruism. In: Berkowitz, L. (Ed.), Advances in Experimental Social Psychology, Volume 10. Academic Press, San Diego, pp. 221-279.

Sheller, M., Urry, J., 2006. The new mobilities paradigm. Environment and Planning A 38(2), 207226.

Shove, E., 2010. Beyond the ABC: climate change policy and theories of social change. Environment and Planning A 42(6), 1273-1285.

Thaler, R.H., Sunstein, C.R., 2008. Nudge: Improving Decisions about Health, Wealth, and Happiness. Yale University Press, New Haven and London.

Thøgersen, J., 2009. Promoting public transport as a subscription service: effects of a free month travel card. Transport Policy 16(6), 335-343.

Thrift, 2007. Non-Representational Theory: Space, Politics, Affect. Routledge, Abingdon.

Thrift, N., 2008a. I just don't know what got into me: where is the subject? Subjectivity 22(1), 8289.

Thrift, N., 2008b. Pass it on: towards a political economy of propensity. Emotion, Space and Society 1(2), 83-96

Triandis, H.C., 1977. Interpersonal Behavior. Brooks/Cole, Monterey, CA.

Urry, J., 2004. The system of automobility. Theory, Culture \& Society 21(4-5), 25-39.

Valentine, G., 1997. "Oh yes I can." "Oh no you can't": children and parents' understandings of kids' competence to negotiate public space safely. Antipode 29(1), 65-89. 
Venn, C., 2010. Individuation, relationality, affect: rethinking the human in relation to the living. Body \& Society 16(1), 129-161.

Verplanken, B., Aarts, H., Van Knippenberg, A., Van Knippenberg, C. 1994. Attitude versus general habit: antecedents of travel mode choice. Journal of Applied Social Psychology 24(4), 285-300.

Verplanken, B., Aarts, H., Van Knippenberg, A., 1997. Habit, information acquisition, and the process of making travel mode choices. European Journal of Social Psychology 27(5), 539-560.

Verplanken, B., Wood, W., 2006. Interventions to break and create consumer habits. Journal of Public Policy \& Marketing 25(1), 90-103.

Verplanken, B., Walker, I., Davis, A., Jurasek, M., 2008. Context change and travel mode choice: Combining the habit discontinuity and self-activation hypotheses." Journal of Environmental Psychology 28(2): 121-127.

Watson, M., this issue. How theories of practice can inform transition to a decarbonised transport system. Journal of Transport Geography.

Weinberger, R., Goetzke, F., 2010. Unpacking preference: how previous experience affects auto ownership in the United States. Urban Studies 47(10), 2111-2128. 